O sintoma e a clínica psicanalítica. O curável e o que não tem cura

Maria Cristina Ocariz São Paulo, Via Lettera, 2003

\title{
A clínica psicanalítica e seus limites
}

\author{
Maria Carolina Ciotola Bruno
}

Quais os limites da clínica psicanalítica? E suas finalidades? Qual a dimensão terapêutica da psicanálise? Quais os critérios de cura para a psicanálise? Até que ponto podemos falar em eficácia em psicanálise?

Essas são algumas das muitas questões que o livro de Maria Cristina Ocariz convoca-nos a pensar durante sua leitura. Questões fundamentais para todos os que, assim como ela, oferecem sua escuta àqueles que procuram ajuda para seu sofrimento, através do tratamento psicanalítico. Suas questões brotam da clínica, de uma clínica madura. Maturidade que facilmente é percebida para quem lê o livro, pela clareza com que desenvolve suas idéias e pela vivacidade que transborda de seu texto.

Seu ponto de partida para essa jornada foi, portanto, a constatação de que vários analisandos acompanhados por ela, ao se aproximarem do término de sua análise, continuavam apresentando determinados sintomas ou até apareciam com novos sintomas. Assim, ela pergunta-se: O que fazer com esses sintomas? O que fazer com os restos incuráveis? O que tem cura e o que não tem cura ao final de uma análise?

Desses questionamentos surge, portanto, este interessantíssimo livro: O sintoma e a clínica psicanalítica. O curável e o que não tem cura. 
R E V I S T A

O caminho escolhido pela autora para fundamentar e sustentar teoricamente suas questões é o de trabalhar profunda e cuidadosamente o conceito de sintoma e suas transformações ao longo das obras de Freud e Lacan, construindo, assim, uma sólida consistência para suas argumentações, além de presentear-nos com um completo e claro estudo sobre o sintoma nesses dois autores, para depois, partindo disso, poder trilhar um caminho particular a respeito dessas questões.

Ao longo de seu primeiro capítulo, “A concepção freudiana de sintoma”, acompanhamos o desenvolvimento das idéias de Freud, dos primeiros esboços e marcas do início da psicanálise até seus últimos textos e elaborações, seguindo, cronologicamente e detalhadamente, o desenvolvimento de praticamente todas as noções fundamentais da psicanálise, tendo sempre como pano de fundo o conceito do sintoma.

De uma maneira clara e precisa, o conceito de sintoma é visto e revisto em todos os momentos e sob todos os aspectos da teoria freudiana.

O segundo capítulo, “A concepção lacaniana de sintoma. Inovações sobre o sintoma na teoria e suas incidências na clínica psicanalítica”, a autora faz, inicialmente, uma apresentação da obra e estilo de Lacan, para depois, de maneira bastante clara e compreensível, trazer os principais conceitos da teoria lacaniana, que irão ajudar-nos a compreender e acompanhar a concepção de sintoma para Lacan. A obra de Lacan, assim como a de Freud, é toda revista do ponto de vista do sintoma, marcando também as principais diferenças em relação à teoria freudiana.

No capítulo 3, “Os sintomas no final de uma análise”, a autora retoma suas questões, fazendo um convite aos leitores a segui-la nos vários caminhos que encontra para pensar sobre elas.

Como pensar em eficácia para psicanálise? A palavra eficácia nos remete à capacidade que a psicanálise tem para lidar com o sofrimento humano, o que nos leva, conseqüentemente, a pensar sobre os resultados, "sobre o que ficou, qual é o saldo” no final de uma análise. Mas como medir isso? Para que isso aconteça "precisamos saber quais são os parâmetros de medição e os modelos, ideais e valores sobre saúde e doença, embutidos na pratica clínica e, também, na pesquisa em psicanálise”, o que muitas vezes, não estão nada claros para os psicanalistas. É uma questão muito importante colocada pela autora, já que o que é terapêutico, os resultados esperados pela a psicanálise diferenciam-se enormemente dos convencionais, principalmente, se a comparamos com a medicina.

A autora coloca a transferência numa posição central nesse processo de cura, ressaltando que a concepção que o analista tem de cura será o que direcionará esse processo e que a psicanálise terá uma concepção bem particular do que é cura, já que, curar é também definir, localizar e delimitar o incurável. 
Reescrever uma história, desconstruir seus mitos, fazer a travessia do seu fantasma e decifrar seus sintomas fazem parte do trabalho da análise, permitindo que o sujeito mude sua posição subjetiva e faça um novo acordo com o gozo ou não - pois, a partir daí, o sujeito pode conscientemente escolher qual o caminho seguirá, abrindo a possibilidade para que possa responder a pergunta: “Quem sou eu? O que eu desejo?”

Mas e os sintomas que daí restam? Voltando à questão principal, a autora coloca que sempre vão existir sintomas, pois não é intenção da psicanálise produzir sujeitos sem conflitos, sem sintoma, e esses que restam são os sintomas "sem casca", que vem do real do sujeito e que melhor o representam e, que, por isso mesmo, serão irredutíveis, e o único trabalho que poderá incidir sobre eles será o de uma mudança da relação desse sujeito com seu sintoma, na medida que, consiga dar a eles uma solução criativa. A psicanálise não visa, portanto, produzir um sujeito perfeito, mas sim alguém que seja sujeito do seu próprio desejo e que consiga suportar o imprevisto, a incerteza, um não-saber que implicará no reconhecimento dos limites impostos pelo real.

Ainda sobre o sintoma, ela coloca que existe "um ponto impossível ao qual chega toda análise. O que não se cura, o incurável tem a ver com a eficácia da palavra para eliminar o plus de satisfação que tem o sintoma; o plus de satisfação que traz o sofrimento. Esse ponto obriga o sujeito a inventar uma solução para seu próprio incurável: o incurável próprio de cada um. É uma solução que não é codificada, que não responde a nenhum padrão de saúde ou doença. Lacan chama este processo de savoir-faire com o sintoma, haver-se com o sintoma, saberfazer com ele".

A autora termina o capítulo trazendo um belo caso clínico, através do qual consegue exemplificar claramente os pontos trabalhados nesse capítulo.

O livro ainda traz, ao final, no capítulo "O recalque na formação de sintomas e a sublimação como alternativa. A sublimação questionada”, um breve estudo sobre a sublimação em Freud e Lacan, procurando, através dessas duas leituras, diferenciar "a satisfação da pulsão por sublimação da satisfação por meio do sintoma”, tentando detectar as possíveis articulações da sublimação com o sintoma.

O livro de Maria Cristina Ocariz, além de tratar de questões sérias e indispensáveis de uma maneira bastante agradável e clara, é um daqueles livros que, do começo ao fim, obriga-nos a pensar (ou repensar) sobre nosso trabalho, a pensar sobre questões que, muitas vezes, deixamos para segundo plano, mas que, na verdade, deveriam ser o pano de fundo de qualquer trabalho clínico psicanalítico. 